\title{
MIGRANTSKA KRIZA KAO IZAZOV SOCIJETALNOJ BEZBEDNOSTI U EVROPSKOJ UNIJI
}

\author{
Spasoje M. Vulević \\ Ministarstvo unutrašnjih poslova Republike Srbije
}

Cilj ovog rada je da se prikaže migrantska kriza kao realna pretnja socijetalnoj bezbednosti Evropske unije i spoznaja da je kolektivni identitet jedan od vodećih faktora u obrascima ponašanja stanovništva i vlada država njenih članica, čija se potreba za samoočuvanjem javila kao posledica velikog priliva migranata muslimana, prvenstveno iz zemalja sa područja severne Afrike i Bliskog istoka.

Ključne reči: migranti, migrantska kriza, bezbednost, socijetalna bezbednost, identitet, nacionalni identitet, Evropska unija

\section{Uvod}

U najširem smislu, pod pojmom migracija (lat. migratio) podrazumeva se seoba, seljenje, preseljenje, iseljenje. ${ }^{1}$ [5] Migracije predstavljaju privremeno ili trajno, dobrovoljno ili prinudno preseljavanje stanovništva, kako unutar granica jedne zemlje (unutrašnje migracije), tako i iz jedne zemlje u drugu (međunarodne migracije). Migranti napuštaju (emigranti) sredinu u kojoj su živeli (emigraciono područje) i dolaze (imigranti) u novu sredinu (imigraciono područje). Na kretanje (tranzit) iz mesta dotadašnjeg življenja (polazište, zemlja porekla) do novog mesta življenja (odredište, zemlja destinacije) migranti prolaze kroz određene georegije (tranzitna područja) i tada se smatraju migrantima u tranzitu. ${ }^{2}$ [12]

Problem migracija izaziva interesovanje evropske javnosti dugi niz godina, a u centar pažnje dolazi u vreme migrantske (izbegličke) krize tokom 2015. godine. Da bi se razumela aktuelna migraciona kriza, koja teče od Afrike, Bliskog istoka i Azije ka Evropi, kao složen i više dimenzionalan fenomen, potrebno je prvo sagledati njene uzroke. Oni se obično analiziraju kroz tzv. push and pull model, koji podrazumeva faktore pritiska (push) koji primoravaju na migratorna kretanja, i faktore koji privlače (pull) ljude na kretanja ka boljim uslovima života. Push faktore mogu predstavljati ratovi i sukobi, represivni režimi i sistematsko ugrožavanje ljudskih sloboda i prava, demografska eksplozija u nekim delovima sveta, siromaštvo, nezaposlenost, rasna, verska, etnička mržnja i netrpeljivost, klimatske promene i prirodne katastrofe. Kao pull faktori mogu se javljati bolji uslovi života, veća bezbednost, poboljšanje socijalnog statusa, političke slobode, verska tolerancija i slično. ${ }^{3}$ [14]

\footnotetext{
${ }^{1}$ Milan Vujaklija, Leksikon stranih reči i izraza, Prosveta, Beograd, 1980, str. 562.

${ }^{2}$ Saša Mijalković, Ivan Petrović, „Bezbednosni rizici savremenih migracija”, NBP.Žurnal za kriminalistiku i pravo, No. 2, 2016, str. 2.

${ }^{3}$ Željko Ninčić, Migrantska kriza kao bezbednosna pretnja, Bezbjednost-policija-građani, godina XII, broj 3-4/16, str. 86.
} 
Ukoliko se ljudi pokreću u traganju za boljim kvalitetom života i zaposlenjem reč je o tzv. ekonomskim migracijama i ekonomskim migrantima, a u slučaju da beže od ratova, sukoba i represivnih režima u zemljama iz kojih dolaze reč je o političkim migracijama - izbeglištvu i izbeglicama, odnosno o traženju azila i azilantima. Ekonomske migracije se pretežno odvijaju na relacijama „siromašni jug - bogati sever” i „siromašni istok - bogati zapad”, dok se migracije u potrazi za bezbednijim okruženjem i ekološke migracije u najvećoj meri odvijaju do bliže bezbedne destinacije u unutrašnjem ili prekograničnom okruženju. ${ }^{4}$ [12]

Procenjuje se da zvanično svake godine u zemlje članice EU iz trećih zemalja legalno stigne oko 2,5 miliona ljudi, dok se u poslednje vreme godišnje zabeleži više od milion zahteva za azil. Evropa je suočena s potencijalnim migrantskim talasom od čak 20 do 25 miliona ljudi, procenio je evropski komesar za proširenje Johanes Han, ocenjujući da će migrantsko pitanje biti najveći izazov 21. veka. Populacija u Africi će se udvostručiti na preko dve milijarde već 2050. godine, a još toliko Afrikanaca će biti do 2100. godine. Ujedinjene nacije procenjuju da broj migranata, odnosno onih koji ne žive u zemlji u kojoj su rođeni trenutno iznosi oko 258 miliona, što predstavlja oko tri odsto ukupne svetske populacije. ${ }^{5}$ [24]

Velika migrantska kriza u Evropi, koja je dostigla svoj vrhunac tokom 2015. godine, proizvela je ozbiljne političke, ekonomske, socijalne, bezbednosne, ekološke i druge posledice u državama kroz koje su migranti tranzitirali ili u kojima su privremeno ili trajno ostajali.

\section{Koncept socijetalne bezbednosti}

Bezbednost je pojam koji je oduvek imao veliki značaj i zauzimao je važno mesto u širokom spektru društvenih nauka. Teško je pouzdano i tačno utvrditi značenje pojma bezbednost. Ne postoji neko opšte prihvaćeno značenje ili definicija ovog pojma. Etimološki, izraz bezbednost nastao je od reči bez (nepostojanje, odsustvo) i beda (veliko siromaštvo, položaj koji izaziva prezir, nevolja, nesreća, zlo) i predstavlja stanje onoga koji je osiguran od opasnosti, zaštićen, siguran, bezopasan. Pored izraza bezbednost, u srpskom jeziku je u upotrebi i izraz sigurnost, koji etimološki vuče koren od latinske securitas - atis (mir duha, bezbrižnost, sigurnost, bezopasnost) i prideva securus (bez brige, bezbrižan, bez bojazni, koji se ne boji nikakve opasnosti). U srpskom jeziku ove dve reči se često upotrebljavaju kao sinonimi, iako reč sigurnost ima širi smisao, naročito u oblasti prvobitnog značenja latinske reči securitas, gde se ne podrazumeva samo odsustvo opasnosti, nego i izvesnost, samopouzdanje. ${ }^{6}$ [21]

Za definisanje pojma bezbednost najčešće se vezuje stanje ugroženosti (nebezbednosti), kao društvena pojava i kategorija koja destruktivno deluje na osnovne vrednosti koje štiti i brani bezbednost. Za potrebe sistema bezbednosti najcelishodnije je određenje ugrožavanja kao opasnosti. Krivično-pravno značenje opasnosti podrazumeva manju ili veću mogućnost uništenja ili oštećenja nekog dobra ili vrednosti. Ugrožavanje je svaka

\footnotetext{
${ }^{4}$ Saša Mijalković, Ivan Petrović, navedeno delo, str. 2.

${ }^{5}$ Goran Čvorović, Evropi preti 25 miliona izbeglica, Večernje novosti, 15.1. 2018. Dostupno preko: http://www.novosti.rs/vesti/planeta.299.html:706275-Evropi-preti-25-miliona-migranata (Pristupljeno: 25.02.2018).

${ }^{6}$ Dragutin Sretović, Miroslav Talijan, Hatidža Beriša, Savremeni koncept bezbednosti, Vojno delo, Beograd, 1/2016, str. 74.
} 
vrsta društvene, prirodne i tehničke opasnosti kojom se ugrožavaju integritet, sloboda, imovina i zdravlje ljudi, kao i teritorijalni integritet i suverenitet i ustavni poredak i pravo države, naroda, nacija ili društvenih grupa i pojedinaca. ${ }^{7}$ [19]

Pri određivanju pojma bezbednosti polazi se, uglavnom, od stava da je bezbednost osnovni atribut države i da je vezan za njenu zaštitnu funkciju. „Bezbednost u najširem političko-pravnom smislu obuhvata mere i aktivnosti čuvanja i zaštite od ugrožavanja nezavisnosti i integriteta jedne zemlje (države, nacije) i unutrašnjeg ustavnog i pravnog poretka. U prvom slučaju se govori o spoljnoj, a u drugom o unutrašnjoj bezbednosti. Prema objektu zaštite razlikuju se: a) nacionalna bezbednost; b) javna bezbednost; v) kolektivna bezbednost; g) lična i imovinska bezbednost." [10] Suština bezbednosti jeste da društvo, odnosno država preko nje ostvaruje određeni cilj, koji se, prevashodno, sastoji u zaštiti sopstvenog opstanka i progresivnog razvitka u skladu sa mogućnostima.

Beri Buzan (Barry Buzan) govori o bezbednosti kao o težnji za slobodom od pretnji i sposobnosti država i društava da održe nezavisnost njihovog identiteta i funkcionalni integritet od promena koje oni vide kao neprijateljske. ${ }^{9}$ [2] Država, odnosno njen teritorijalni integritet dugo vremena bio je centralni referentni objekat bezbednosti, usled opravdanog straha od rata. Ali, sa novonastalom situacijom na svetskoj sceni u fokus dolaze nove pretnje koje više ne proizilaze isključivo iz vojnog sektora. Padom Berlinskog zida, raspadom Sovjetskog Saveza i Varšavskog pakta i okončanjem hladnog rata pažnju nisu više privlačile isključivo vojna i politička pitanja već su ekonomski, društveni i ekološki problemi našli svoj put ka dnevnom redu međunarodnog bezbednosnog sistema. ${ }^{10}$ [2]

Kopenhaška škola studija bezbednosti (okupljena oko Kopenhaškog instituta za istraživanje mira - COPRI) i njeni istaknuti predstavnici Beri Buzan (Barry Buzan), Ole Vejver (Ole Waever) i De Vilde (Jaap de Wilde), devedesetih godina razvili su „teoriju sekuritizacije" koja podrazumeva sektorski pristup bezbednosti, ukazujući na to da u svakom od ovih sektora postoje različiti referentni objekti i pretnje, tako da država (i vojna pretnja) više nije centralna, odnosno osnovna tačka u studijama bezbednosti. Ovi sektori su međusobno ispreplitani i ne funkcionišu izolovano. Postoji pet sektora bezbednosti: vojni, politički, ekonomski, socijetalni i ekološki. ${ }^{11}[7]$

U ovom kontekstu vojni sektor podrazumeva odnose moći, politički - odnose autoriteta, ekonomski - ekonomske odnose, ekološki - odnose čoveka i prirode, a socijetalni sektor - odnose društvenih grupa. Naravno, svi ovi sektori se međusobno prepliću i utiču jedni na druge, tako da se striktno odvajanje sektora koristi samo u analitičke svrhe, jer u stvarnosti većina bezbednosnih problema predstavlja kombinaciju više bezbednosnih sektora. $^{12}[15]$

\footnotetext{
${ }^{7}$ Ljubomir Stajić, Osnovi bezbednosti, Policijska akademija, Beograd, 2004, str. 43.

${ }^{8}$ Mala politička enciklopedija, Savremena administracija, Beograd, 1966.

${ }^{9}$ Bary Buzan, New patterns of global security in the twenty-frst century, Royal Institute of International Affairs 1944-, Vol. 67, No. 3, July 1991, pp. 432.

${ }^{10}$ Barry Buzan, navedeno delo, pp. 433.

${ }^{11}$ Filip Ejdus, Međunarodna bezbednost: teorije, sektori i novoi, JP Službeni glasnik i Beogradski centar za bezbednosnu politiku, Beograd, 2012., str. 114.

${ }^{12}$ Branka Panić, Socijetalna bezbednost - bezbednost $i$ identitet, Bezbednost Zapadnog Balkana, Centar za civilno-vojne odnose, Beograd, Godina 4, broj 13, april-jun 2009, str. 31.
} 
U vojnom sektoru, koji je bio dominantan dugo vremena, proučavaju se odnosi između država, njihovih oružanih ofanzivnih i defanzivnih sposobnosti, kao i sposobnosti država za međusobnu percepciju namera. ${ }^{13}$ [24] Ovde najučestaliju pretnju predstavlja vojna invazija. Tako je za vreme hladnog rata postojala stalna pretnja od izbijanja nuklearnog rata između supersila ili u periodu pre početka Drugog svetskog rata Nemačka koja je bila pretnja evropskim zemljama. U političkom sektoru fokus je na organizacionoj stabilnosti poretka i ideologiji koja vlastima u jednoj državi daje legitimitet. Primer jedne ovakve pretnje jeste revolucija i širenje različite ideologije među narodom. Ekonomski sektor karakterišu trgovinski odnosi, pristup resursima, finansije, održavanje prihvatljivog nivoa socijalne i državne vlasti. ${ }^{14}$ [24] Ovde je referentni objekat međunarodni liberalni ekonomski poredak, a primer pretnje može biti Svetska ekonomska kriza iz 2008. godine. U ekološkom sektoru ključni su odnosi između čoveka i prirode, održavanje biosfere kao sistema od kojeg zavisi celo čovečanstvo. Čovek na različite načine negativno utiče na prirodu, pa to ima za posledicu zagađenje i klimatske promene koje stvaraju pretnju po ekološki sektor i izazivaju UV zračenje, globalno zagrevanje, pojavu cunamija i podizanje nivoa mora. ${ }^{15}[7]$

Na međunarodnoj sceni se, pored država, sve češće pojavljuju i drugi akteri, pojedinci i društvene grupe kao što su terorističke organizacije i multinacionalne kompanije. ${ }^{16}$ [7] Posle hladnog rata stvorena je nova bezbednosna struktura i napravljena je važna razlika između države i društva. Dok državu čine njene teritorijalne granice, institucije, suverenost i njen narod, društvo čini kolektivni identitet koji taj narod povezuje u jedinku, kao i njegov jezik, religija i kultura. Upravo ovom oblašću bavi se socijetalni sektor bezbednosti. Ukoliko je kolektivni identitet jednog naroda ugrožen, to društvo nije socijetalno bezbedno, nije u stanju da sačuva ono što ono u prirodi jeste, ono što ga čini posebnim, jedinstvenim i drugačijim od drugih. U slučaju socijetalne bezbednosti referentni objekat bezbednosti nije država (kao vlada niti kao teritorijalni entitet), već je to zajednički kolektivni identitet. U tom smislu bezbednost društva može biti ugrožena svime što ugrožava taj identitet. Upravo se u bezbednosti kolektivnog identiteta nalazi osnovna razlika između socijetalne bezbednosti i socijalne sigurnosti, koja se odnosi na pojedinca i pretežno je ekonomske prirode.

Beri Buzan socijetalnu bezbednost definiše kao „održiv razvoj tradicionalnih obrazaca jezika, kulture, religijskih i nacionalnih identiteta, kao i običaja države". ${ }^{17}$ [3] Ole Vejver (Ole Waever) socijetalnu bezbednost vidi kao „sposobnost društva da očuva svoje suštinske osobine usled promenljivih okolnosti i uprkos mogućim ili stvarnim pretnjama”. ${ }^{18}$ [23] Kritiku ovog koncepta dao je Meksvini (Bil McSweeney) koji smatra da pripadnici Kopenhaške škole (kako im je on sam nadenuo to ime) na pogrešan, objektivistički način razumeju identitet. Kako kaže ,identitet nije društvena činjenica, već proizvod pregovaranja između ljudi i interesnih grupa”. ${ }^{19}$ [13]

\footnotetext{
${ }^{13}$ Paul D. Williams, Security Studies: An Introduction, Routledge, London and New York, 2008, pp. 4.

${ }^{14}$ Paul D. Williams, navedeno delo, pp. 4.

${ }^{15}$ Filip Ejdus, navedeno delo, str. 116.

${ }^{16}$ Filip Ejdus, navedeno delo, str. 177.

${ }^{17}$ Barry Buzan, People, States and Fear: An Agenda dor International Security Studies in the Post-Cold War Era, Harvester Wheatsheaf, London, 1991, pp. 122-123.

${ }^{18}$ Ole Waever, Barry Buzan, Moltren Kelstrup and Pierre Lemaitre, Identity, Migration and the New Security Agenda in Europe, Pinter, London, 1993, pp. 23.

${ }^{19}$ Bil McSweeney, Security, Indentity and Interests: A Sociology of International Relations, Cambridge University Press, Cambridge, 1999, pp. 73.
} 
Zajednički kolektivni identitet povezuje ljude na jedan poseban način, čineći ih pripadnicima određene društvene grupe. Jedno društvo može smatrati da je ugrožen njegov nacionalni, etnički, verski, rodni, seksualni, rasni, plemenski, civilizacijski ili bilo koji drugi identitet koji čini da se identifikuje sa zajednicom. Na ugroženost kolektivnog identiteta najčešće ukazuju nedržavni akteri, predstavnici opozicionih partija i pokreta, verske vođe i intelektualci. Društvo se s pretnjama može izboriti tako što će: jačati svoj kolektivni identitet, smanjiti uticaj tuđeg identiteta i tako što će se problem prebaciti u vojni ili politički sektor, gde može doći do oružanog sukoba, genocida, anti migracione politike i deportacije. ${ }^{20}$ [7]

\section{Pojam identiteta u kontekstu Evropske unije}

Čovek po svojoj prirodi ima potrebu da pripada nečemu što je veće i snažnije od njega kao pojedinca. On se identifikuje sa određenom društvenom grupom u skladu sa onim što on jeste, vođen ideologijom i praksom. Sopstvenost se sastoji od više identiteta i uloga. Svaki od tih identiteta - familijarni, teritorijalni, klasni, religijski, etnički i polni može biti modifikovan ili čak ukinut. ${ }^{21}[18]$ Iz današnje perspektive, najmoćniji u političkom smislu jesu nacionalni i verski identitet. ${ }^{22}$ [7] Identitet je definisan kao skup ideja i praksi koje određene pojedince identifikuju kao pripadnike jedne socijalne grupe. Dok su nacije apstraktne i zamišljene zajednice, nacionalni identitet najznačajniji je referentni objekat socijetalne bezbednosti. ${ }^{23}$ [15]

Nacionalni identitet uključuje određeni smisao političkog zajedništva, zajedničkih institucija i određenih prava i dužnosti za sve članove zajednice. Takođe, on podrazumeva definisani socijalni prostor i označenu ograničenu teritoriju sa kojom se članovi zajednice identifikuju, tj. za koju razvijaju osećaj pripadnosti. Antoni Smit (Anthony Smith) naciju definiše kao zajednicu ljudi koji poštuju ista pravila i institucije u okviru određene teritorije. On govori o dva modela nacije - etničkom i zapadnom modelu, odnosno o civilnom modelu nacije, koji prvenstveno predstavlja prostorni ili teritorijalni koncept. Prema zapadnom modelu, nacija mora da poseduje kompaktnu, dobro definisanu teritoriju. To ne može biti bilo koja i bilo kakva teritorija, već mora biti istorijska zemlja, domovina, kolevka jednog naroda. Smit izdvaja osnovne karakteristike nacionalnog identiteta koji ga ujedinjavaju i učvršćuju: istorijska teritorija, tj. domovina, zajednički mitovi i istorijska memorija, zajednička kultura, zajednička prava i dužnosti svih članova zajednice i zajednička ekonomija koja podrazumeva teritorijalnu mobilnost svih članova. ${ }^{24}$ [15]

U 19. veku Francuska i Američka revolucija donele su velike promene na Zapadu i u Evropi. Dolazi do pojave nacionalizma kao moderne ideologije koja je donela ne samo jednakost među građanima u okviru jedne države već i osećaj povezanosti građana kroz identitet, zajedništvo i pripadnost. Članovi jedne nacije dele zajednički socijalni, kulturni i politički identitet. Nacionalizam ističe ideju narodnog suvereniteta i demokratije, kao i legitimitet suverene države koja počiva na sposobnosti vlada da vladaju „u skladu sa vred-

\footnotetext{
${ }^{20}$ Filip Ejdus, navedeno delo, str. 186.

${ }^{21}$ Anthony D. Smith, National Identity, Penguin Group, London, 1991., pp. 9.

${ }^{22}$ Filip Ejdus, navedeno delo, str.182

${ }^{23}$ Branka Panić, navedeno delo, str. 31.

${ }^{24}$ Branka Panić, navedeno delo, str. 31.
} 
nostima, interesima i identitetom naroda". ${ }^{25}$ [4] Nacionalizam je promenio razumevanje koncepta državne bezbednosti, koji ne podrazumeva više samo upotrebu sile i sposobnost države da se odbrani od pretnji, unutrašnjih i spoljnih, već i potrebu za legitimitetom i socijalnom kohezijom. Dok je za vreme hladnog rata težište bilo na spoljnoj dimenziji bezbednosti, u vremenu koje je usledilo nakon njega etnički konflikti i građanski ratovi stupaju na scenu, kao i pitanja unutrašnje stabilnosti i kohezije. ${ }^{26}[4]$

Isticanje socijalne kohezije je upravo ono što je dovelo do proširenja koncepta bezbednosti, izvan vojnog sektora, na šta je ukazala tzv. Kopenhaška škola. Evropski identitet je jačao kroz proces koji je doveo do stvaranja Evropske unije - od Evropske zajednice za ugalj i čelik, koja se smatra početkom evropske integracije, stvaranja Evropske ekonomske zajednice, Evropske monetarne unije i stvaranja Evrozone, gde postoji jedinstvena valuta evro. Snaga nacionalizma u državama članicama suzbijena je kroz razvoj određenih mehanizama, ali su nacionalni identiteti i dalje neodvojivi deo građana EU. ${ }^{27}$ [8] Jedan od načina suzbijanja nacionalizma jeste decentralizacija institucionalne strukture nacionalnih država kroz stvaranje nadnacionalnih institucija. Tako su u institucionalnoj strukturi EU stvorene nadnacionalne političke institucije - Evropski parlament, Savet Evrope i Evropski sud pravde. Ove institucije imaju pravo zaključivanja ugovora i stvaranja političke, pravne i monetarne unije.

Ideja je bila stvaranje postnacionalne Evrope kroz ograničavanje vlasti u državama članicama i stvaranje protivteže u vidu nadnacioanlnih političkih snaga. Suverena nacionalna država je ograničena i kroz primenu međunarodno priznatih pravnih garancija nacionalnog identiteta, kroz usvajanje Ženevskih konvencija i Univerzalne deklaracije o pravima čoveka iz 1948 godine.

Jedna od ključnih stvari Evropske unije, kao dobrovoljne integracije država Evrope i njenih građana, jesu prava i slobode građana koji oni uživaju kao njeni pripadnici. To je još jedan način jačanja evropskog građanstva. U oblasti prava građana i unutrašnje bezbednosti Evropska unija ima četiri glavne kategorije politika: a) slobodno kretanje lica između država članica Evropske unije, polazeći od prava na rad i nastanjivanje do uklanjanja graničnih kontrola između država članica; b) osnovna prava za državljane Evropske unije u drugim državama članicama, kakva su jednakost ekonomskih, političkih i građanskih prava; v) politike imigracije i azila, koje podrazumevaju saradnju u politikama prema izbeglicama i zajedničke politike prema državljanima trećih zemalja; g) policijska i pravosudna saradnja u borbi protiv trgovine drogama, terorističkih aktivnosti, prekograničnog kriminala i ilegalne imigracije. ${ }^{28}$ [22]

\section{Pretnje socijetalnoj bezbednosti}

Referentni objekat socijetalne bezbednosti jeste kolektivni identitet. Ukoliko u datom trenutku postoji realna mogućnost da dođe do neželjene promene kolektivnog identiteta jednog društva, to znači da postoje pretnje po socijetalnu bezbednost tog društva. Pret-

\footnotetext{
${ }^{25}$ Barry Buzan and Lene Hansen, The Evolution of International Security Studies, Cambridge University Press, New York, 2009., pp.27

${ }^{26}$ Barry Buzan and Lene Hansen, navedeno delo, pp. 29.

${ }^{27}$ Džon Kin, Civilno društvo: Stare slike, nove vizije, Filip Višnjić, Beograd, 2003, str. 128-139.

${ }^{28}$ Sajmon Hiks, Politički sistem Evropske unije, Službeni glasnik, Beograd, 2007, str. 325.
} 
nje po kolektivni identitet mogu dolaziti iz samog socijetalnog sektora, ali mogu dolaziti i iz političkog, vojnog, ekonomskog i ekološkog sektora. Kada pretnje dolaze iz samog socijetalnog sektora, to znači da kolektivnom identitetu preti drugi kolektivni identitet. Beri Buzan (Barry Buzan), Ole Vejver (Ole Waever) i De Vilde (Jaap de Wilde) iz Kopenhaškog instituta za istraživanje mira - COPRI, ukazuju na četiri grupe pretnji po socijetalnu bezbednost: migracije, horizontalno nadmetanje, vertikalno nadmetanje i depopulacija. ${ }^{29}$ [7] Za potrebe ovog rada u nastavku će biti prikazane i objašnjene migracije kao jedna od najvećih pretnji socijetalnoj bezbednosti. Da li će domaće stanovništvo imigraciju videti kao pretnju zavisi od očuvanja njihovog nacionalnog identiteta.

Pojam migracija podrazumeva kretanje stanovništva, emigraciju i imigraciju. Emigracija označava izlazak iz zemlje porekla, zemlje čije državljanstvo emigrant ima, dok imigracija podrazumeva ulazak u zemlju domaćina, koja je imigrantu strana. Migracija pretpostavlja trajno preseljenje iz zemlje porekla u stranu zemlju, što je razlikuje od prostorne mobilnosti. Devedesetih godina 20. veka najviše je bilo migranata iz bivšeg Sovjetskog saveza (SSSR), zatim migranata koji su tražili zaštitu usled sukoba u njihovim zemljama (sa prostora bivšeg SSSR i bivše Jugoslavije) i tranzitnih migranata, migranata iz drugih zapadnih zemalja i zemalja u razvoju koji čekaju na potvrdu svog statusa u zemlji u koju žele da imigriraju. ${ }^{30}$ [11] Postoji i problem takozvanih incomplete migrants ${ }^{31}$ [11]. To su migranti koji nisu uspeli da dođu do željene destinacije, a nisu uspeli ni da nađu sklonište u tranzitnoj zemlji. Sa ekonomskim kolapsom sedamdesetih godina dolazi do promena odnosa prema pitanju migracija, jer su evropske zemlje od tada prestale da prihvataju radnike iz stranih država. Građani su nezadovoljstvo iskazivali kritikujući države i društva da su previše otvoreni za strance. Došlo je do velikih socijalnih promena koje su uticale na kvalitet života ljudi. Odnos prema imigrantima se znatno promenio, smatrani su jednim od razloga koji je doprineo finansijskoj krizi, većoj stopi kriminaliteta i lošem radu političkih i drugih institucija, koje u javnosti sve više kritikovane. Postepeno su naglašavane razlike u kulturnim, jezičkim i religijskim običajima imigranata, kao i njihov status u društvu. Socijalna nesigurnost ljudi, loša ekonomska situacija, recesija, društvene promene, institucionalno preopterećenje i druge poteškoće koje su se pojavile posle velikih imigracija doživljavani su kao problemi socijalne sigurnosti koji dovode do pretnji po socijetalnu bezbednost i kao posledica prisustva velikog broja imigranata. ${ }^{32}$ [23]

Usledile su promene i na političkoj sceni država, zabeležen je rast polarizacije nacionalne politike, pojavile su se i ojačale partije koje vode anti migracionu politiku. Zapadne zemlje su nekada bile homogene države, svaka sa svojim nacionalnim identitetom, političkom, jezičkom i tradicionalnom kulturom. Svaka od ovih zemalja imala je i nacionalne manjine na svojoj teritoriji. Međutim, sa ekspanzijom migranata dolazi do obrazovanja multi kulturalnog društva u kojem je heterogenost prirodna, što podrazumeva suživot više različitih kultura i rasa na istom prostoru, u granicama jedne države. Procenjuje se da je u Nemačkoj 1989.

\footnotetext{
${ }^{29}$ Filip Ejdus, navedeno delo, str. 186.

${ }^{30}$ Douglas S. Massey, J. Edward Taylor, International Migration: Prospects and Policies in a Global Market, Oxford University Press, New York, 2004, pp. 38.

${ }^{31}$ Douglas S. Massey, J. Edward Taylor, navedeno delo, pp. 40.

${ }^{32}$ Ole Waever, Barry Buzan, Morten Kelstrup, and Pierre Lemaitre, Identity, Migration and the New Security Agenda in Europe, St. Marin's Press, New York, 1993., pp. 157.
} 
godine živelo 1,6 miliona Turaka, 606.000 Jugoslovena, 521.000 Italijana i 295.000 Grka. $^{33}$ [23] Migranti u post kolonijalnom periodu bili su asimilirani u domaće stanovništvo, tako što su prihvatali njihov jezik, kulturu, običaje i vrednosti, ali etnički i kulturni diverzitet posleratnih migranata doveo je u pitanje sposobnost njihove asimilacije i prilagođavanja.

Moderne migracije, po mišljenju Stendinga (Guy Standing), imaju sedam karakteristika. ${ }^{34}$ [20] Prva je pojava visoke stope nedokumentovanih migracija. Vlade pojedinih država namerno dopuštaju određeni nivo ilegalnih imigracija, jer im je to u interesu. S jedne strane, ilegalni radnici, koji zvanično ne postoje, predstavljaju jeftinu radnu snagu, a s druge strane, ukoliko je to neophodno, oni svakog časa mogu biti deportovani. Druga karakteristika odnosi se na cirkulaciju migranata. Ranije su migranti odlazili u stranu zemlju sa namerom da tamo izgrade svoju budućnost, ali danas sve češće menjaju svoje mesto boravka, od države do države, kako bi radili privremene poslove i slali novac svojim porodicama. Treća odlika je feminizacija migracija. Češće nego ranije žene imigriraju kako bi radile, zbog sklapanja brakova, ali i zbog bavljenja kriminalnim aktivnostima kao što su prostitucija i trgovina ljudima. Četvrta karakteristika je mobilnost studenata. Mnogi fakulteti daju stipendije stranim studentima kako bi oni bili u mogućnosti da dođu i studiraju u inostranstvu. Peta odlika jeste postojanje multinacionalnih korporacija, a s tim u vezi i ljudi koji svoje karijere grade u inostranstvu. Šesta karakteristika modernih migracija ogleda se u tome da nikada nije bilo više izbeglica i ljudi koji traže azil. Novu grupu migranata čine izbeglice koje traže utočište u drugoj zemlji, usled promena nastalih u njihovoj sredini. Sve ove karakteristike dovode do transformacije globalnog društva i do novih opasnosti.

$\mathrm{U}$ ozbiljne bezbednosne reperkusije migracija, pogotovo ako su one neregularne, svrstava se i povećani rizik od unutrašnjih i međudržavnih konflikata na tlu, pre svega, jugoistočne Evrope, kao i porast raznih vidova kriminala, prvenstveno krijumčarenja migranata, trgovine ljudima i drugih krivičnih dela koja imaju veze sa migracijama (falsifikovanje isprava, ilegalno prelaženje državne granice, posredovanje u ilegalnom prelaženju državne granice, otmica, prinuda, prostitucija i sl.). Porast obima i raznovrsnosti organizovanog kriminala, koji uz to poprima složenije mrežne forme i transnacionalne dimenzije, svakako ugrožava nacionalnu, ali pre svega ljudsku bezbednost. Smatra se da je posle ilegalne trgovine narkoticima i oružjem, trgovina ljudima, u koju je uključen veliki broj migranata, najisplativija aktivnost organizovanog kriminala koji je, početkom ovog veka, samo u Evropi godišnje donosio profit od nekoliko milijardi dolara. ${ }^{35}$ [17]

\section{Stvaranje Evropske unije}

Evropska unija predstavlja dobrovoljnu integraciju evropskih država na ekonomskom i političkom nivou. lako poseduje neke od elemenata države, Evropska unija je politički sistem, a ne država. ${ }^{36}$ [22] Potreba za ujedinjenjem evropskih naroda datira još od 14.

\footnotetext{
${ }^{33}$ Ole Waever, Barry Buzan, Morten Kelstrup, and Pierre Lemaitre, navedeno delo, pp. 159.

${ }^{34}$ Guy Standing, The Precariat: The New Dangerous Class, Bloomsbury Academic, London, 2011, pp. 91-93.

${ }^{35}$ Dragan Simeunović, Migraciona kriza kao bezbednosni izazov za zemlje Zapadnog Balkana - stanje $u$ 2017. i perspektiva, Kultura Polisa, posebno izdanje, Godina XIV, Novi Sad, 2017, str. 3.

${ }^{36}$ Sajmon Hiks, navedeno delo, str. 24-26.
} 
veka, kada je Pjer Duboa (Pierre Dubois) predložio da Evropskom konfederacijom upravlja Evropski savet sačinjen od „mudrih, stručnih i vernih muškaraca”. ${ }^{37}$ [1] Ali, prvi konkretni koraci ka evropskom jedinstvu načinjeni su posle 1945. godine, kada su evropski narodi shvatili da je za njihov opstanak bitno stvaranje unije evropskih država. Prvi razlog tome bila je bezbednost, kao i postizanje trajnog mira u Evropi. Evropske zemlje su u istoriji više puta međusobno ratovale, pa je zaključak bio da ukoliko se ove zemlje približe jedna drugoj, rat više neće biti ni prihvatljivo rešenje, ni logičan razvoj situacije. Poučeni iskustvom iz Prvog i Drugog svetskog rata, strahom od ponovne invazije Nemačke, kao i uzdizanjem SAD i SSSR-a kao dve najveće sile, Evropa je morala da učini nešto što će je dovesti do statusa ravnopravnog člana u borbi za svetskom moći i prestižom. U vezi s tim, smatra se da je drugi razlog za evropsko jedinstvo ekonomski prosperitet i stabilnost. Otvoreno tržište između država članica stimuliše međunarodnu trgovinu roba, usluga, kapitala i radne snage, što dovodi i do ekonomskog prosperiteta koji označava stabilnost u ekonomskom i svakom drugom smislu.

Početak Evropske unije bila je Zajednica za ugalj i čelik (ECSC - European Coal and Steel Community), nastala potpisivanjem Ugovora iz Pariza 1951. godine između šest zemalja - Francuske, SR Nemačke, Belgije, Italije, Luksemburga i Holandije (tzv. šestorke). Cilj zajednice bio je uklanjanje carina (carinska unija), ograničenja uvoznih kvota na ugalj, gvožđe i čelik, kao i jednak pristup svake od zemalja potpisnica ovim proizvodima. To je ujedno bio i način da se dva istorijska neprijatelja - Francuska i Nemačka trajno obavežu i pomire. Ugovor iz Rima, na osnovu kojeg su nastale Evropska ekonomska zajednica (EEC - European Economic Community) i Evropska zajednica za atomsku energiju (EAEC European Atomic Energy Community, Euratom), potpisan je 25. marta 1957. godine. Od 1958. godine postojala su tri odvojena entiteta: Evropska zajednica za ugalj i čelik, Evropska ekonomska zajednica i Euratom. Svaka od ovih zajednica imala je svoje institucije, pa je šestorka 1965. godine potpisala Ugovor o spajanju institucija sa kojim je stvorena jedinstvena struktura oličena u Evropskoj zajednici (EC - European Community) sa Komisijom, Parlamentom, Savetom ministara i Evropskim sudom pravde, kao njenim institucijama. Još jedan korak dalje ka stvaranju Evropske unije bio je donošenje Jedinstvenog evropskog akta (SEA - Single European Act) koji je stupio na snagu 1. jula 1987. godine, a čiji je cilj bio stvaranje jedinstvenog tržišta do kraja 1992. godine. On je podrazumevao slobodno kretanje proizvoda, usluga, kapitala i radne snage. Konačno, Ugovor o Evropskoj uniji (TEU - ), poznat i kao Ugovor iz Mastrihta (The Treaty of Maastricht), potpisan je 1992. godine, a stupio je na snagu 1. novembra 1993. godine, sa kojim je Evropska zajednica postala deo šire Evropske unije (EU - European Union). ${ }^{38}[1]$

Ugovor iz Mastrihta postavio je Evropsku uniju na tri stuba, tako da liči na antički hram: 1) prvi stub obuhvata tri zajednice: Evropsku zajednicu za ugalj i čelik, Evropsku ekonomsku zajednicu i Euratom; 2) drugi stub obuhvata zajedničku spoljnu i bezbednosnu politiku; 3) treći stub obuhvata saradnju u oblasti pravosuđa i unutrašnjih poslova. ${ }^{39}$ [6] Prvi i drugi stub imaju međuvladin karakter, dok je treći stub nadnacionalnog karaktera. Ugovorom iz Amsterdama, koji je potpisan 1997. godine, neki aspekti trećeg stuba

\footnotetext{
${ }^{37}$ Ali El-Agraa, The European Union: Economics and Policies, Cambridge University Press, New York, 2011, pp. $19-20$.

${ }^{38}$ Ali El-Agraa, navedeno delo, pp. 30.

${ }^{39}$ Desmond Dinan, Encyclopedia of the European Union, Lynne Rienner Publishers, London, 1998., pp. 464-465.
} 
prebačeni su u prvi stub. Došlo je do zaključka da su kontrola spoljnih granica, vize, azil i imigraciona politika, koji su se nalazili u trećem stubu, bliži nacionalnom suverenitetu i da treba da budu svrstani u prvi stub. Ugovorom iz Amsterdama dodat je novi naslov (IV) Ugovoru o Evropskoj uniji, kojim je stvorena zona slobode, bezbednosti i pravde. ${ }^{40}$ [22] Zona slobode podrazumeva slobodno kretanje ljudi, zaštitu osnovnih prava i borbu protiv diskriminacije. Zona bezbednosti označava borbu protiv kriminala, terorizma, trgovine ljudima, narkoticima, oružjem i borbu protiv korupcije i pronevere. Zona pravde podrazumeva jednak pristup pravdi za sve građane Evropske unije, saradnju između država članica u građanskim oblastima i postizanje minimuma zajedničkih pravila država članica u vezi sa kriminalom, krivičnim procedurama i kaznama. ${ }^{41}$ [22] Ugovor iz Lisabona (Ugovor o funkcionisanju EU - UFEU), koji je potpisan 2007. godine, a postao operativan od 1. decembra 2009. godine, ukinuo je institucionalnu strukturu stubova u Evropskoj uniji, koju danas čini 28 zemalja članica.

\section{Ukidanje unutrašnjih granica - Šengenski sporazum}

Slobodno kretanje ljudi, još od Ugovora iz Rima, postavljeno je kao osnovni cilj Evropske ekonomske zajednice. To se u početku odnosilo isključivo na prekograničnu ekonomsku aktivnost. Državljani država članica imali su pravo da traže posao na teritoriji drugih država članica, kao i pravo da u njima borave, pružaju ili primaju usluge. Kroz sekundarno zakonodavstvo i kroz presude Evropskog suda pravde ova prava su proširena i na one ljude koji zavise od državljana EU, kao što su to supružnici i deca i na ekonomski nezavisna lica koja nisu državljani EU, a u tu grupu spadaju studenti, lica koja imaju dovoljno novčanih sredstava kako ne bi bila na teretu države prijema, zaposleni u kompanijama i samozaposleni. ${ }^{42}$ [22]

Sporazum iz Šengena potpisalo je 1985. godine pet zemalja članica Evropske zajednice - Francuska, Nemačka, Belgija, Holandija i Luksemburg. To je bio sporazum o ukidanju graničnih kontrola između ovih država potpisnica. Ciljevi Šengenskog sporazuma bili su olakšavanje personalnih putovanja preko granica, smanjenje provera na minimum kada su u pitanju komercijalna putovanja, utvrđivanje nekih zajedničkih pravila vizne politike i politike azila, jačanje saradnje država u vezi sa trgovinom narkoticima, oružjem, terorizmom, fiskalnim prevarama, ilegalnim migracijama, kao i regulisanje prava policijske potere preko nacionalnih granica. ${ }^{43}$ [6] Sporazum je trebalo da stupi na snagu 1. januara 1990. godine. Međutim, države nisu bile potpuno sigurne kako će on uticati na pitanja od domaćeg značaja, a Nemačka je i javno iznela razloge svoje zabrinutosti. Ona je tražila više vremena za promatranje na koji način će Sporazum uticati na prava građana iz Istočne Nemačke (Nemačka je u tom periodu još uvek bila podeljena na Zapadnu i Istočnu Nemačku, sve do pada Berlinskog zida i ujedinjenja Nemačke 1990. godine).

\footnotetext{
${ }^{40}$ Sajmon Hiks, navedeno delo, str. 325-326.

${ }^{41}$ Sajmon Hiks, navedeno delo, str. 326.

${ }^{42}$ Sajmon Hiks, navedeno delo, str. 326-328.

${ }^{43}$ Desmond Dinan, navedeno delo, pp. 412-414.
} 
Zbog nedoumica zemalja potpisnica Šengenski sporazum nije stupio na snagu 1. januara 1990. godine, ali su se države dogovorile oko novih pregovora i 15. juna 1990. godine potpisale dopunjeni sporazum - Šengen 2, koji je precizirao uslove i garancije slobodnog kretanja. Ratifikovale su ga svi nacionalnih parlamenti država potpisnica. Ovim sporazumom propisana su pravila koja se tiču zahteva za azil, kao što je princip „first handling"44 [6], koji propisuje da država koja je prva obradila zahtev za azil neke osobe ostaje nadležna do kraja u slučaju te osobe. Svaka država potpisnica obavezuje se da će prihvatiti nazad izbeglice koje borave na drugoj teritoriji država potpisnica. Odluke o azilu, koje donese bilo koja od država potpisnica, obavezujuće su za sve države potpisnice. Sporazumom nije predviđen nadnacionalni nadzor primene odredbi sporazuma u državama članicama. Sporazum iz Šengena potpisale su i Italija (1990), Portugal, Španija (1991), Grčka (1992), Austrija (1995), Danska, Finska, Švedska (1996), Kipar, Češka Republika, Estonija, Mađarska, Letonija, Litvanija, Malta, Poljska, Slovačka, Slovenija i Švajcarska (2004), Rumunija i Bugarska (2007). ${ }^{45}$ [16]

Sa ukidanjem unutrašnjih granica i stvaranjem Šengen zone moguće bezbednosne pretnje fokusirane su u prvi plan. Kao jedan od načina kontrolisanja bezbednosnih pretnji stvoren je Šengenski informacioni sistem (SIS), sa sedištem u Strazburu. Ovaj efikasan sistem velikih razmera doprinosi spoljnoj kontroli granica i omogućava saradnju država članica Evropske unije na tom polju. ${ }^{46}$ [25] To je baza podataka koju ovlašćene institucije zemalja potpisnica koriste kako bi dobile informacije o određenim kategorijama ljudi i predmeta. Tu se nalaze podaci o osobama za kojima je raspisana poternica, podaci o potencijalnim svedocima, o nestalim osobama i osobama koje se ciljano nadgledaju. Takođe, tu se registruju i vozila, lične karte, oružje i bankovni računi koji su ukradeni. ${ }^{47}[16]$ Informacije se ubacuju u bazu podataka preko nacionalnih mreža (N-SIS) država koje su povezane sa centralnim sistemom (C-SIS) koji omogućava policiji i graničarima da prate upozorenja i ne pruža samo informacije o određenoj osobi ili predmetu, već i instrukcije o tome šta treba uraditi ukoliko se ta osoba ili predmet pronađu.

Bitan deo funkcionisanja SIS-a predstavlja specijalizovana Mreža dodatnih zahteva za informacijama sa nacionalnog nivoa - SIRENE (Supplementary Information REquest at the National Entries), koja omogućava dodatnu razmenu podataka i usklađivanje aktivnosti u vezi sa uzbunama Šengenskog informacionog sistema i stalno je operativna. Glavni cilj Šengenskog informacionog sistema jeste očuvanje unutrašnje bezbednosti država potpisnica Šengenskog sporazuma zbog odsustva unutrašnjih graničnih kontrola. Šengenski informacioni sistem je operativan u svim državama članicama Evropske unije koje su potpisnice Šengenskog sporazuma. Postoje posebni uslovi za države koje su članice Evropske unije, ali nisu potpisnice Šengenskog sporazuma. Šengenska zona obuhvata većinu država članica osim Bugarske, Hrvatske, Kipra, Irske, Rumunije i Velike Britanije. Postoje i četiri pridružene zemlje koje su deo Šengenske zone - Švajcarska, Norveška, Lihtenštajn i Island, koje takođe učestvuju u SIS-u.

\footnotetext{
${ }^{44}$ Desmond Dinan, navedeno delo, pp. 413.

${ }^{45}$ Rečnik evropske bezbednosti, Centar za civilno-vojne odnose, Beograd, 2010.

${ }^{46}$ European Commission, Migration and Home Affairs, Schengen Information System, Dostupno preko: https://ec.europa.eu/home-affairs/what-we-do/policies/borders-and-visas/schengen-information-system_en, (Pristupljeno: 5. 2. 2018).

${ }^{47}$ Rečnik evropske bezbednosti, Centar za civilno-vojne odnose, Beograd, 2010.
} 
Pored Šengenskog informacionog sistema, za uspešno funkcionisanje prostora bez unutrašnjih granica, tj. Šengen zone, neophodno je ustanovljavanje zajedničke vizne politike. Ona omogućava licima trećih država legalan boravak na teritoriji država potpisnica Šengenskog sporazuma jačajući unutrašnju bezbednost ove zone. Evropska unija je usvojila zajedničku viznu politiku tzv. „Šengen vize” za kratke boravke, tj. boravke do tri meseca ${ }^{48}$ [26] U savremenom dobu razvoja informacionih sistema prepoznato je da tehnologija može imati bitnu ulogu u jačanju i poboljšanju zaštite spoljnih granica. Tako je Evropska unija razvila Vizni informacioni sistem (VIS - Visa Information System) koji podržava implementaciju zajedničke politike viza EU i omogućava razmenu podataka o vizama između država u Šengen zoni. Sastoji se od centralnog sistema i komunikacione infrastrukture koja povezuje ovaj centralni sistem sa nacionalnim sistemima. U okviru VIS-a obrađuju se podaci i odluke u vezi sa zahtevima za dobijanje viza za kratak boravak ili tranzit kroz zemlje Šengena. Sistem ima mogućnost da vrši biometrijska podudaranja otisaka u svrsi identifikacije i verifikacije.

Evropska unija je u oblasti unutrašnjih poslova ustanovila agencije, koje se po oblastima delovanja bave posebnim zadacima. To je bitno kako bi se život u prostoru bez unutrašnjih granica nesmetano odvijao, sa saznanjem da se na polju zaštite od potencijalnih bezbednosnih pretnji konstantno radi. Agencije FRONTEX, Europol, CEPOL, EMCDDA, EASO i eu-LISA imaju svoje jedinstvene funkcije i zajedno obezbeđuju informacije i savete, donose odluke, nadgledaju operacije i pružaju podršku kreiranju politika. ${ }^{49}$ [27] Evropski savet za pravosuđe i unutrašnje poslove je od 1999. godine radio na jačanju saradnje u oblasti migracija, azila i bezbednosti. To je dovelo do ustanovljavanja External Border Practitioners Common Unit, jedinice stručnjaka za spoljne granice, koju su činili članovi Strateškog odbora za imigracije, granice i azil (SCIFA - Strategic Committee on Immigration, Frontiers and Asylum) i šefovi nacionalnih službi granične kontrole. Uspostavljeno je šest ad-hok centara. ${ }^{50}$ [28]

Kako bi se poboljšale procedure i metode rada, Evropski savet je dve godine nakon osnivanja ad-hoc centara 2004. godine osnovao Evropsku agenciju za upravljanje operativnom saradnjom na spoljnim granicama država članica Evropske unije - FRONTEX (European Agency for the Management of Operational Cooperation at the External Borders of the Member States of the European Union). Sedište agencije nalazi se u Poljskoj, u Varšavi. FRONTEX pomaže Evropskoj uniji u upravljanju spoljnim granicama i time doprinosi slobodi i sigurnosti njenih građana. Pomaže u nadzoru spoljnih granica EU i kontroli osoba, vrši obuke nacionalnih graničnih službi, uspostavlja zajedničke standarde obuke, obavlja analizu rizika, pruža tehničku i operativnu pomoć, kao i podršku u organizovanju zajedničkih operacija povratka. Šengenska zona predstavlja prostor bez unutrašnjih granica 28 zemalja, koje se međusobno oslanjaju jedna na drugu, vodeći računa da će kontrole na spoljnim granicama svake od njih biti na visokom nivou, što su one, kao potpisnice Šengenskog sporazuma i dužne da obezbede. Kontrola granica spada u od-

\footnotetext{
${ }^{48}$ European Commission, Migration and Home Affairs, Visa Policy, Dostupno preko:https://ec.europa.eu/homeaffairs/what-we-do/policies/borders-and-visas/visa-policy_en (Pristupljeno: 5. 2. 2018).

${ }^{49}$ European Commission, Migration and Home Affairs, Agencies, Dostupno preko: https://ec.europa.eu/home-affairs/what-we-do/agencies_en\#6 (Pristupljeno: 5. 2. 2018).

${ }^{50}$ Videti detaljnije: European Border and Coast Guard Agency, FRONTEX, Dostupno preko: http://frontex.europa.eu/about-frontex/origin/, (Pristupljeno: 15. 1. 2018).
} 
govornost svake nacionalne države. Uloga FRONTEX-a je koordinacija dodatnih stručnjaka i tehničke opreme u graničnim područjima koji se nalaze pod nekim velikim pritiskom. ${ }^{51}$ [29] Buduće operacije FRONTEX-a planiraju se i razvijaju na osnovu „Godišnjeg izveštaja o analizi rizika" (Annual Risk Analysis Report) u kojem se analiziraju budući rizici ilegalnih migracija i pograničnog kriminala.

\section{Odgovor Evropske unije na migrantsku krizu}

Jedan od glavnih uzroka velike migrantske krize koja je pogodila Evropu, čija kulminacija je bila tokom 2015. godine, predstavljalo je tzv. Arapsko proleće, talas demokratskih promena koje su se desile u Severnoj Africi i na Bliskom istoku, koji je počeo u decembru 2010. godine, što je rezultiralo uklanjanjem dotadašnjih diktatora iz arapskih zemalja ovog regiona (Tunis, Egipat, Libija, Jemen). Građanski rat koji je od 2012. godine eskalirao u Siriji jedan je od ključnih razloga zbog kojeg Evropska unija nije u mogućnosti da se na najbolji način nosi sa situacijom nastalom u okviru njenih granica. Priliv migranata koji beže iz Sirije ka Evropskoj uniji je ogroman i zajedno sa migrantima iz Avganistana, Iraka, Eritreje i drugih zemalja severne Afrike i srednjeg istoka stvara problem velikih razmera sa kojim se Evropa suočava.

U skladu sa Ženevskom konvencijom o statusu izbeglica iz 1951. godine, zemlje Evropske unije dužne su da ponude utočište imigrantima koji beže od rata ili progona u zemlji porekla. Među imigrantima koji stižu u Evropsku uniju većina je onih kojima je zaštita zaista potrebna, kao što su imigranti iz Sirije, Eritreje, Avganistana i Iraka. Ali, tu su i imigranti koji žele da pobegnu od loših uslova života, bede, tzv. ekonomski imigranti koji većinom dolaze iz Nigerije, Pakistana i sa Balkana. Postoje i imigranti koji su već dobili azil u nekoj zemlji, ali zbog nezadovoljstva i teškog života u toj zemlji pokušavaju da dođu do druge zemlje koja će im pružiti bolje uslove za njihovu budućnost. Među 4,4 miliona Sirijica koji su raseljeni izvan granica svoje države, $90 \%$ se nalaze u tri države - Turskoj, Jordanu i Libanu. Zbog toga što rat u Siriji traje već godinama (u martu 2018. godine ušao je u osmu godinu trajanja), resursi i mogućnosti u ove tri zemlje se sve više smanjuju. Priliv migranata je sve veći, pa ove države nemaju dovoljno resursa ni mogućnosti da isprate tempo koji novi migranti stvaraju. Zato migranti odlaze dalje, u Evropsku uniju, nadajući se da će uspeti da stignu do nje i da će im zahtev za azil biti odobren.

Jedan od stimulansa koji migrante dodatno podstiče na kretanje jesu i socijalni mediji koji izveštavaju o ljudima koji su uspeli da dobiju status azilanta u državi u kojoj su podneli zahtev. Takođe, imigranti su svesni sporog procesa razmatranja aplikacija za azil, pa im to pruža mogućnost da ilegalno putuju kroz Evropu, a kao jedan od možda najjačih razloga kretanja migranata jeste ponovno spajanje sa porodicama i prijateljima. Većina imigranata koji stignu u Evropsku uniju ( njih 70\%) jesu muškarci koji su ostavili svoje porodice, a nakon dobijanja statusa azilanta planiraju da ih dovedu.

Postoji više razloga zbog kojih je Evropska unija suočena sa migrantskom krizom u teškom trenutku. Prvi je, svakako, situacija u kojoj se Evropska unija nalazi, odnos između nje-

51 FRONTEX, Roles and Responsibilities, Dostupno preko: http://frontex.europa.eu/operations/roles-andresponsibilities/, (Pristupljeno: 5. 1. 2018). 
nih država članica je poljuljan, solidarnost je ispod očekivanog nivoa, zatim i nestabilnost poretka usled ekonomske krize i sporog ekonomskog oporavka, političko vođstvo je slabo, a dolazi i do rasta populističkih partija i partija koje se protive konceptu EU. Sve to dovelo je do slabljenja Evropske unije, kao i jačanja nacionalnih identiteta naspram podrške Evropskoj integraciji. Problem sa rešavanjem migrantske krize jesu i različiti socijalni stavovi država članica o migracijama, kao i politička osetljivost ovog pitanja. Potreban je snažan koherentni kolektivni odgovor za rešavanje krize, ali zemlje nisu u stanju da se dogovore zbog svojih asimetričnih stavova i različitog uticaja problema migracije na svaku od njih.

lako su već imale sisteme bezbednosti državnih granica, mnoge države bile su organizaciono i funkcionalno nespremne da se suoče sa ovim problemom. Reakcija i iznuđeni odgovor na masovnost migracija često nije bio u skladu sa prirodom i složenošću problema - odbijanje prijema izbeglica i tražilaca azila, podizanje zidova i zaštitnih ograda i postavljanje policijskih kordona na granici (primeri Mađarske, Bugarske, Makedonije). Takvo postupanje ima sva obeležja sekundarne viktimizacije neadekvatnim odgovorom državnih organa, odnosno ponovnog stvaranja žrtava od lica koja su već žrtve oružanih konflikata (izbeglice) i represivnih režima (azilanti). Ovakav represivni i nehumani odnos prema izbeglicama i azilantima uticao je na pogoršanje imidža pojedinih zemalja u međunarodnim odnosima i doživeo osudu međunarodne zajednice. ${ }^{52}$ [12]

Evropska unija je od početka migrantske krize imala nekoliko predloga i rešenja za ublažavanje njenih posledica:

- Obavezne kvote, kako bi se tražioci azila preraspodelili u zemlje širom Evropske unije. Evropski savet se složio da će 160.000 tražilaca azila biti preseljeno u okviru teritorije EU. lako se želelo da se pomogne i olakša Grčkoj i Italiji, ovaj proces se ipak odvija jako sporo. Samo mala grupa migranata je premeštena, a razlog je odbijanje pojedinih zemalja da prihvate migrante na svojoj teritoriji (Rumunija, Češka, Slovačka i Mađarska).

- Dogovor sa Turskom. Evropska unija je odobrila dogovor sa Turskom vredan tri milijarde evra, kako bi Turska zadržala što je moguće veći broj migranata na svojoj teritoriji i na taj način smanjila njihov priliv u Evropu. Ovde je bilo dosta razmirica između zemalja o tome koliko koja zemlja treba da dâ novca. Turski predsednik Redžep Taip Erdogan je $\mathrm{u}$ jednom trenutku zapretio da će poslati autobuse pune migranata na granicu sa Evropom, ukoliko ne dobiju obećani novac. Turskoj su ponuđeni i novi pregovori za članstvo u EU, kao pozitivan odgovor na napore koje ova zemlja čini u ublažavanju posledica migrantske krize.

- Postavljanje hotspots prihvatnih centara u Grčkoj i Italiji za registrovanje novih migranata, kako bi razdvojili migrante kojima je zaista potrebna međunarodna zaštita od ekonomskih migranata. Postoje 5 ovakvih centara u Grčkoj i nekoliko u Italiji. Grčka se nalazi pod pretnjama da će biti izbačena iz Šengen zone ukoliko njeni „hotspotovi” ne počnu brzo da funkcionišu.

- Jačanje spoljnih granica EU - više sredstava za FRONTEX, čiji bi pripadnici patrolirali spoljnim granicama Unije. Priča o panevropskim pograničnim snagama izazvala je kontroverze o suverenitetu zemalja.

- Reforma Šengena i Dablinske regulacije - pregovaranje o izmenama i podizanju bezbednosnih provera građana Evropske unije prilikom ulaska u Šengen zonu.

\footnotetext{
${ }^{52}$ Saša Mijalković, Ivan Petrović, navedeno delo, str. 5-6.
} 
- Sporazumi o deportaciji. Evropska unija se nadala potpisivanju sporazuma sa zemljama severne Afrike i Azije (zemljama iz kojih dolazi najviše migranata i izbeglica), kako bi se tražioci azila koji su odbijeni vratili u svoje zemlje u zamenu za novac i pomoć. Mnogi od ovih sporazuma su se, za sada, pokazali kao neostvarivi.

- Humanitarna pomoć za Siriju i region. Organizovana je međunarodna Konferencija za prikupljanje novca u Londonu. $^{53}$ [30]

S obzirom na to da jedan broj država članica Unije zatvara svoje granice za imigrante, uvode vizne restrikcije i sankcije za letenje avionom, migranti pronalaze različite načine kako bi došli do granica država gde žele da podnesu zahtev za azil. Imigranti često koriste opasne rute, preko mora, uz pomoć krijumčara, koji im ne garantuju bezbedno dolaženje na željenu destinaciju. Veliki broj imigranata, uključujući i decu, izgubio je živote u pokušaju da stignu u Evropsku uniju. ${ }^{54}$ [31] Prema podacima Međunarodne organizacije za migracije (IOM - International Organization for Migration), u 2017. godini u migrantskim tokovima i na migrantskim rutama prema Evropi poginulo je ili nestalo 5.386 osoba, od čega 3.119 u Mediteranu. U ovaj broj nisu uračunate žrtve koje su stradale bez svedoka. ${ }^{55}$ [32] Grupa evropskih novinara je u aprilu 2014. godine objavila rezultate istraživanja, za čiju osnovu su koristili bazu podataka UNITED mreže od oko 560 nevladinih organizacija iz celog sveta, koji pokazuju da je od 2000. godine smrtno stradalo preko 23.000 migranata i izbeglica u pokušaju da se domognu boljeg života u nekoj od evropskih zemalja. ${ }^{56}$ [33]

\section{Posledice i anomalije u Evropskoj uniji prouzrokovane migracijama}

U nastojanju da zaustave i kontrolišu preveliki priliv migranata u zemlje Evropske unije, mnoge od njenih članica su, u nedostatku opšteg i obavezujućeg stava, počele da preduzimaju samostalne državne mere na tom planu. Osim izostajanja željenog efekta, ove mere su doprinele i menjanju slike o demokratskom statusu tih zemalja i ukazale na brojne raskorake između proklamovanih principa i propisa EU i antimigracione prakse. Ove anomalije i posledice ukazale su na velike probleme u načinu organizacije i funkcionisanja strukture EU i dovele do preispitivanja osnovnih principa na kojima Unija počiva. Veliko i neprijatno saznanje predstavljalo je ponašanje jednog broja država koje stavljaju svoje nacionalne interese na prvo mesto (nacionalno i pojedinačno iznad nadnacionalnog i kolektivnog), što onemogućava postizanje jednog zajedničkog evropskog rešenja za migrantsku krizu. Migrantska kriza pokazala je ispravnim upozorenja i tvrdnje o po-

\footnotetext{
${ }^{53}$ Nina Schick, No European solution on the migration crisis in sight, Open Europe, Dostupno preko: http://openeurope.org.uk/today/blog/no-european-solution-on-the-migration-crisis-in-sight/, (Pristupljeno: 10. 1. 2018).

${ }^{54}$ Natalia Banulescu-Bogdan and Susan Fratzke, Europe's Migration Crisis in Context: Why Now and What Next?, Migration Polisy Institute, Dostupno preko:http://www.migrationpolicy.org/article/europe-migration-crisiscontext-why-now-and-what-next, (Pristupljeno:11, 1. 2018).

${ }^{55}$ Goran Čvorović, Evropi preti 25 miliona migranata, Večernje novosti, 15. 1. 2018. Dostupno preko: http://www.novosti.rs/vesti/planeta.299.html:706275-Evropi-preti-25-miliona-migranata, (Pristupljeno: 25. 2. 2018).

${ }^{56}$ Mrtve izbeglice pred vratima Evrope, RTS - Dojče vele, 9. 4. 2014. Dostupno preko: http://www.rts.rs/page/stories/ci/story/2160/prenosimo/1570990/mrtve-izbeglice-pred-vratima-evrope.html (Pristupljeno: 12. 3. 2018).
} 
vratku otpisane nacionalne države i odbačenog nacionalnog suvereniteta na političku scenu Evrope, o čemu svedoči podizanje zidova, obnova nacionalnih granica i postavljanje graničara na odavno izbrisane nacionalne granice širom EU.

Veliku anomaliju predstavlja činjenica da se zabranom prolaska izbeglica krši globalni princip slobode kretanja ljudi, roba i ideja na kojem je zasnovan čitav koncept EU. Tome treba dodati i nepoštovanje ljudskih prava migranata, naročito prava na naturalizaciju, kao i odluku EU da se svi migranti koji nisu iz Avganistana, Iraka i Sirije proglase za ekonomske migrante, čime se odabirom zemlje porekla vrši diskriminacija i narušava pravo migranata da kao pojedinci pristupe azilnim procedurama, što je i UNHCR kritikovao. ${ }^{57}$ [17]

Anomaliju svakako predstavlja i odluka Mađarske, Hrvatske i Slovenije da na svojim granicama podignu zaštitne ograde i zidove, jer se radi o zemljama u kojima izbeglice uopšte ne nameravaju da ostanu, već žele da kroz njih što pre prođu do konačnih destinacija (Nemačke, Austrije, Švedske, Francuske i drugih zemalja Unije). Poseban problem predstavlja odbijanje pojedinih država članica EU da prihvate određene kvote za prijem jednog broja migranata na svojoj teritoriji. Naime, da bi oslobodili pritiska Grčku i Italiju, lideri EU su kvalifikovanom većinom, u septembru 2015. godine, usvojli mehanizam raspodele malog dela od oko 1,7 miliona migranata koji su od 2014. godine stigli u Evropu. Na prethodnih 40.000 izbeglica, dodato je još 120.000 koje je trebalo solidarno razmestiti u roku od dve godine. Mađarska je bila u obavezi da primi još 1.294 migranta, odnosno ukupno više od 2.300, a Slovačka još 802 , odnosno ukupno oko 1.500 migranata. Međutim, zemlje Višegradske grupe - Poljska, Češka, Slovačka i Mađarska nisu glasale za ovaj plan, smatrajući, pored ostalog, da bi to nasilno promenilo strukturu stanovništva. Budimpešta i Bratislava su zatim podnele žalbu Evropskom sudu pravde sa sedištem u Luksemburgu, s ocenom da je sistem kvota nepravičan, neefikasan, kao i da na ovaj način nije ispoštovana pravna procedura. Ali, Sud pravde EU je početkom septembra 2017. godine u potpunosti odbacio njihove žalbe, uz zaključak da sistem efektivno i proporcionalno doprinosi olakšavanju situacije u Grčkoj i Italiji. Takođe, ocenio je opravdanom odluku koja je doneta većinom, a ne konsenzusom, bez javne rasprave, konsultovanja parlamenta i referenduma, zbog hitnosti situacije. Mehanizam kvota je ocenjen validnim, a protiv ove odluke ne postoji pravo žalbe. Ali, prve izjave predstavnika zemalja koje odbijaju određene kvote upućuju na to da će se malo šta promeniti, uprkos odluci najvišeg evropskog suda.

„Poljska i dalje neće primati migrante po kvotama za njihovu raspodelu koje predviđa plan EU, uprkos tome što Brisel ima pravo da prisili države članice da prihvate tražioce azila" - izjavila je u prvoj reakciji poljska premijerka Beata Šidlo, dok je mađarski ministar spoljnih poslova Peter Sijarto u svom komentaru na odluku suda rekao da je „politika silovala evropsko pravo i vrednosti". Mađarska i Poljska do septembra 2017. godine nisu primile nijednog izbeglicu, Slovačka je prihvatila 16, a Češka desetak. Ipak, jasno je da ove zemlje nisu jedini krivci i da plan o kvotama za raspodelu migranata na nivou EU ne funkcioniše kako je planirano. Od predviđenih 160.000 migranata, mesec dana pre isteka roka, bilo je raspoređeno svega 27.428 migranata, i to 19.216 iz Grčke i 8.212 iz Italije. ${ }^{58}$ [34]

\footnotetext{
${ }^{57}$ Dragan Simeunović, navedeno delo, str. 36.

${ }^{58}$ Goran Čvorović, Zbog izbeglica EU preti članicama, Večernje novosti, 6. 9. 2017. Dostupno preko: http://www.novosti.rs/vesti/planeta.299.html:684433-Brisel-ima-pravo-da-prisili-Slovacku-i-Madjarsku-da-primemigrante-Foto, (Pristupljeno: 22. 2. 2018).
} 
Odbijajući da prime izbeglice te zemlje pokazuju da imaju jednostran odnos sa EU - hoće samo korist od EU, bez namere da uzvrate solidarnošću na potrebe EU, kada je ona kao zajednica u problemu. Time pokazuju da članstvo u EU nije povezano sa imanjem izvesnih odgovornosti. ${ }^{59}$ [17]

Migrantska kriza dovela je do polarizacije političke klime u kojoj sve više preovlađuju nacionalističke i anti migracione partije. Eskalacija migrantske krize u leto 2015. godine, kada je više od milion tražilaca azila iz islamskih zemalja došlo u Evropsku uniju, dovela je do jačanja populističkih pokreta. Oni zahtevaju od Evropske unije da zatvori svoja vrata za muslimanske migrante, da ukine islamističke škole, kao i da se muslimanskim ženama zabrani da pokrivaju svoju kosu i lice u javnosti. U Francuskoj su neke opštine donele zakon o zabrani nošenja burki. U Danskoj je odobren „Jewerly Law” koji dozvoljava vladi da konfiskuje vrednosti od migranata u zamenu za njihov boravak i smeštaj. Migrantska kriza dovela je do porasta nacionalizma širom Evropske unije, što je primoralo političke partije da se preusmere prema desničarskim stavovima i na taj način odstupe od svojih glavnih principa tolerancije, otvorenosti, raznolikosti i multikulturalnosti. ${ }^{60}$ [35] Događaji u Evropi i svetu od pobede Donalda Trampa na predsedničkim izborima u SAD, zatim i Bregzit u Velikoj Britaniji, kao i jačanje desno orijentisanih partija, znatno menjaju strukturu Evrope i potresaju osnove na kojima ona počiva. Stav desničarskih partija koji one pokušavaju da prenesu na građane Evrope jeste da migranti uzimaju poslove građanima EU, da su muslimani pretnja za evropsku kulturu i bezbednost i da politička korektnost ometa mogućnost da se iznosi ono što se zaista misli. Evidentno je da dolazak velikog broja migranata, najvećim delom iz muslimanskih zemalja, otvara veliki prostor za desnicu na političkoj sceni Evrope.

$\mathrm{Na}$ jačanje desničarskog ekstremizma u Evropi uticala je i opasnost od islamističkog terorizma, budući da je ogroman procenat migranata muslimanske veroispovesti. Sa dolaskom velikog broja migranata iz zemalja u kojima se vode građanski ratovi i u kojima su prisutne razne terorističke grupacije, raste i rizik od terorizma, kako u tranzitnim zemljama, tako i u zemljama u kojima trajno ostaju. Iskustva pokazuju da su među teroristima i džihadistima koji su tokom 2015, 2016. i 2017. godine izveli terorističke napade na tlu zapadne Evrope (Francuska, Belgija, Nemačka, Velika Britanija, Švedska, Spanija), bili veoma zastupljeni upravo imigranti muslimani. To se odnosi na skorašnje imigrante, kao i na tzv. drugu i treću generaciju imigranata, potomke posleratnih (Drugi svetski rat) imigranata koji su rođeni na tlu Evrope.

\section{Zaključak}

Posle hladnog rata pojavio se jedan novi, složeniji model pristupa bezbednosti država, nacija, okoline i pojedinaca. Ovaj pristup znatno odstupa od tradicionalističkog uskog koncepta, ne samo zato što težište stavlja na ne vojna pitanja, već i zato što tvrdi da nešto može postati bezbednosno pitanje čak i onda kada ne predstavlja pretnju državama.

\footnotetext{
${ }^{59}$ Dragan Simeunović, navedeno delo, str.36.

${ }^{60}$ Simon Shuster, European Politics Are Swinging to the Right, TIME, Sep 22, 2016, Dostupno preko: http://time.com/4504010/europe-politics-swing-right/, (Pristupljeno: 2. 2. 2018).
} 
Bezbednost se više ne može tradicionalno izjednačiti sa vojnom bezbednošću ili sa upotrebom sile. Različite ne tradicionalne pojave, poput migracija ili izazova kulturnom identitetu, mogu da potpomognu sekuritizaciji identiteta. Posebno zanimljiv jeste koncept socijetalne bezbednosti, u kojem referentni objekat predstavlja kolektivni identitet, tj. identitet jedne društvene grupe. Cinjenica je da se migracije, secesije ili integracije veoma često pominju kao pretnje po bezbednost, posebno po bezbednost kolektivnog identiteta.

Izbeglička kriza, koja se pretvorila u migrantsku krizu i preti da se transformiše u veliku seobu naroda, još jednom je pokrenula široku debatu o budućnosti Evropske unije, odnosno pitanje njene transformacije. Otvoreno je i pitanje prirode daljih unutrašnjih integracija, zatim pitanje dinamike, pa čak i svrhe daljeg proširenja i, najzad, prirode odnosa sa susedstvom. Takođe, u prvom planu opšte evropske debate jeste odnos prema postojećim vrednostima i institucijama, njihovoj hijerarhiji i prioritetima, prema daljim institucionalnim i vrednosnim transformacijama unutar država članica, kao i u samoj Uniji. Jedna od promena koja se nameće jeste ona u oblasti upravljanja kulturnim različitostima, jačanje interkulturalnog dijaloga kao unapređenog multikulturalizma. Međutim, veliki priliv izbeglica (migranata) izaziva kod dela građana strahove od promene nacionalnog identiteta i načina života, što populisti koriste u političke svrhe, pretvarajući te strahove u argumente za ostvarivanje svojih političkih ciljeva. ${ }^{61}$ [9]

Jedna od ključnih anomalija i posledica sa kojima se suočila Evropska unija u velikoj migrantskoj krizi, posebno tokom 2015 i 2016. godine, jeste činjenica da su propisi, principi, pa i vrednosti Evropske unije nejaki u sukobu sa pojedinačnim interesima država članica. Jedni su u tome videli potrebu da se transformacija EU vrši „prirodno” u pravcu jačanja država članica, dok su drugi u krizi koja je pokazala slabosti funkcionisanja EU videli priliku da se unutar Unije naprave korekcije i pomaci u regulisanju odnosa država članica među sobom i njihovog odnosa prema Uniji, odnosa koji bi značio veću povezanost i funkcionalnije zajedničke institucije. ${ }^{62}$ [9]

Pored humanitarnih i bezbednosnih izazova, pitanja mesta i uloge EU na globalnom planu, migrantska kriza otvorila je i pitanje demografskih perspektiva i ekonomskih pogodnosti koje može doneti veliki migrantski talas (procene su da je dolazak većeg broja migranata doprineo rastu BDP u Nemačkoj). Masovni priliv izbeglica iz Azije i Afrike u Evropu ukazuje na istorijske razmere demografskih pomeranja i moguće globalne posledice, ali zemlje članice EU problem posmatraju i iz sopstvenog, nacionalnog ugla. Otuda rasprave i protesti povodom narušavanja etničke slike, ali i debate o dobroj strani priliva migranata iz ekonomskih razloga. ${ }^{63}[36]$

Migrantska kriza 2015. godine pokrenula je preispitivanje funkcionalnosti EU kao nadnacionalne zajednice država i pitanje njene uloge na globalnom političkom planu, s

\footnotetext{
${ }^{61}$ Zoran Lutovac, Migracije i evropske integracije Srbije, Stanovništvo, Institut društvenih nauka - Centar za demografska istraživanja, Beograd, broj 54/2016, str. 44.

${ }^{62}$ Zoran Lutovac, navedeno delo, str. 44.

${ }^{63}$ Vladajuće političke partije u Nemačkoj postigle su, 14. aprila 2016. godine, dogovor o otvaranju 100.000 radnih mesta za izbeglice koje će finansirati Vlada, kako bi se ubrzala integracija više od 1,1 milion izbeglica i migranata koji su zatražili azil u Nemačkoj. Prema sporazumu, zaposlenje migranata biće limitirano na tri godine, nakon čega će mesta koje ne mogu da popune nemački ili državljani EU biti ukinuta . 24 SATA: Nemačka otvara 100.000 radnih mesta za migrante, 14. 4. 2016, Dostupno preko: http://24sata-vesti.com/nemackaotvara-100000-radnih-mesta-za-migrante/171255 (Pristupljeno: 20. 2. 2018).
} 
obzirom na to da je suočena sa otklanjanjem posledica, a da nije adekvatno uključena u rešavanje problema koji proizvode te posledice. Odnos prema migrantskoj krizi, bezbednosnim izazovima usled ekspanzije terorističkih akcija i pretnji, kao i odnos prema dužničkoj krizi u Grčkoj i Bregzitu (izlasku Velike Britanije iz članstva u EU) pokazali su da je, za sada, EU uspela da sačuva jedinstvo i ostane na pravcu jačanja integrativnih nadnacionalnih institucija i politika, prevladavši zahteve za renacionalizaciju i jačanje država članica u odnosu na centralu u Briselu. Međutim, migrantska kriza je u vrlo izraženoj formi pokazala da postoje ozbiljni problemi u koncepciji EU kao nadnacionalnoj zajednici i velika neslaganja između zemalja članica, a obnavljanje migrantske krize u narednom periodu ove izazove i probleme bi još više produbilo.

\section{Literatura}

[1] Agraa E. A.: The European Union: Economics and Policies, Cambridge University Press, New York, 2011.

[2] Buzan B.: New patterns of global security in the twenty-frst century, Royal Institute of International Affairs 1944-, Vol. 67, No. 3, 1991.

[3] Buzan B.: People, States and Fear: An Agenda dor International Security Studies in the Post-Cold War Era, Harvester Wheatsheaf, London, 1991.

[4] Buzan B. and Hansen L.: The Evolution of International Security Studies, Cambridge University Press, New York, 2009.

[5] Vujaklija M.: Leksikon stranih reči i izraza, Prosveta, Beograd, 1980.

[6] Dinan D.: Encyclopedia of the European Union, Lynne Rienner Publishers, London, 1998.

[7] Ejdus F.: Međunarodna bezbednost: teorije, sektori i novoi, JP Službeni glasnik i Beogradski centar za bezbednosnu politiku, Beograd, 2012.

[8] Kin Dž.: Civilno društvo: Stare slike, nove vizije, Filip Višnjić, Beograd, 2003.

[9] Lutovac Z.: Migracije i evropske integracije Srbije, Stanovništvo, Institut društvenih nauka Centar za demografska istraživanja, Beograd, broj 54/2016.

[10] Mala politička enciklopedija, Savremena administracija, Beograd, 1966.

[11] Massey S. D, Taylor J. E.: International Migration: Prospects and Policies in a Global Market, Oxford University Press, New York, 2004..

[12] Mijalković S, Petrović I.: Bezbednosni rizici savremenih migracija, NBP. Žurnal za kriminalistiku i pravo, No. 2, 2016.

[13] McSweeney B.: Security, Indentity and Interests: A Sociology of International Relations, Cambridge University Press, Cambridge, 1999.

[14] Ninčić Ž.: Migrantska kriza kao bezbednosna pretnja, Bezbjednost-policija-građani, godina XII, broj 3-4/2016.

[15] Panić B.: Socijetalna bezbednost - bezbednost i identitet, Bezbednost Zapadnog Balkana, Centar za civilno-vojne odnose, Beograd, godina 4, broj 13, april-jun 2009.

[16] Rečnik evropske bezbednosti, Centar za civilno-vojne odnose, Beograd, 2010.

[17] Simeunović D.: Migraciona kriza kao bezbednosni izazov za zemlje Zapadnog Balkana stanje u 2017. i perspektiva, Kultura Polisa, posebno izdanje, godina XIV, Novi Sad, 2017.

[18] Smith D. A.: National Identity, Penguin Group, London, 1991.

[19] Stajić Lj, Osnovi bezbednosti, Policijska akademija, Beograd, 2004.

[20] Standing G.: The Precariat: The New Dangerous Class, Bloomsbury Academic, London, 2011. 
[21] Sretović D, Talijan M, Beriša H.: Savremeni koncept bezbednosti, Vojno delo, Beograd, 1/2016.

[22] Hiks S.: Politički sistem Evropske unije, Službeni glasnik, Beograd, 2007.

[23] Waever O, Buzan B, Kelstrup M. and Lemaitre P.: Identity, Migration and the New Security Agenda in Europe, Pinter, London, 1993.

[24] Williams P.D.: Security Studies: An Introduction, Routledge, London and New York, 2008.

[25] https://ec.europa.eu/home-affairs/what-we-do/policies/borders-and-visas/schengeninformation-system_en (Pristupljeno: 5. 2. 2018).

[26] https://ec.europa.eu/home-affairs/what-we-do/policies/borders-and-visas/visa-policy_en (Pristupljeno: 5. 2. 2018).

[27] https://ec.europa.eu/home-affairs/what-we-do/agencies_en\#6 (Pristupljeno: 5. 2. 2018).

[28] http://frontex.europa.eu/about-frontex/origin/, (Pristupljeno: 15. 1. 2018).

[29] http://frontex.europa.eu/operations/roles-and-responsibilities/, (Pristupljeno: 15. 1. 2018).

[30] http://openeurope.org.uk/today/blog/no-european-solution-on-the-migration-crisis-in-sight/, (Pristupljeno: 10. 1. 2018).

[31] http://www.migrationpolicy.org/article/europe-migration-crisis-context-why-now-and-1what-next, (Pristupljeno: 11. 1. 2018).

[32] http://www.novosti.rs/vesti/planeta.299.html:706275-Evropi-preti-25-miliona-migranata (Pristupljeno: 25. 2. 2018).

[33] http://www.rts.rs/page/stories/ci/story/2160/prenosimo/1570990/mrtve-izbeglice-predvratima-evrope.html (Pristupljeno: 12. 3. 2018).

[34] http://www.novosti.rs/vesti/planeta.299.html:684433-Brisel-ima-pravo-da-prisili-Slovacku-iMadjarsku-da-prime-migrante-Foto (Pristupljeno: 22. 2. 2018).

[35] http://time.com/4504010/europe-politics-swing-right/ (Pristupljeno: 2. 2. 2018).

[36] http://24sata-vesti.com/nemacka-otvara-100000-radnih-mesta-za-migrante/171255 (Pristupljeno: 20.02.2018). 